\title{
CONTROL OF SALMONELLA ENTERICA SEROVAR ENTERITIDIS IN LAYING HENS BY INACTIVATED SALMONELLA ENTERITIDIS VACCINES
}

\author{
Oliveiro Caetano de Freitas Neto*; Aline Lopes Mesquita; Jaqueline Boldrin de Paiva; Fábio Zotesso; \\ Angelo Berchieri Júnior
}

Departamento de Patologia Veterinária, Faculdade de Ciências Agrárias e Veterinárias, Universidade Estadual Paulista Júlio de Mesquita Filho, Jaboticabal, SP, Brasil

Submitted: April 13, 2007; Returned to authors for corrections: October 16, 2007; Approved: March 18, 2008.

\begin{abstract}
Salmonella Enteritidis is one of the agents that is responsible for outbreaks of human foodborne salmonellosis caused by Salmonella Enteritidis and is generally associated with the consumption of poultry products. Inactivated Salmonella Enteritidis cell vaccine is one of the available methods to control Salmonella Enteritidis in breeders and laying hens, however results in terms of efficacy vary. This vaccine has never been tested in Brazil, therefore, the present work was carried out to assess three commercial inactivated Salmonella Enteritidis vaccines allowed in Brazil. Four hundred white light variety commercial laying hens were obtained at one-day-of age. At eight weeks old, the birds were divided into four groups with one hundred animals each. Birds from three groups $\left(V_{1}, V_{2}\right.$ and $\left.V_{3}\right)$ received different intramuscular vaccines, followed by a booster dose at 16 weeks of age. Birds from another group (CG) were not vaccinated. When the laying hens were 20,25 and 31 weeks old, 13 from each group were transferred to another room and were challenged by inoculating $2 \mathrm{~mL}$ neat culture of Salmonella Enteritidis. On the second day after each challenge, the caecal contents, spleen, liver and ovary of three birds from each group were analyzed for the presence of Salmonella Enteritidis. Twice a week a cloacal swab of each bird was taken and all eggs laid were examined for the presence of Salmonella Enteritidis. After four consecutive negative cloacal swabs in all the groups, the birds were sacrificed so as to examine the liver, caecal contents and ovaries. Overall, the inactivated vaccine used in group $\mathrm{V}_{3}$ reduced Salmonella Enteritidis in the feces and eggs. A very small amount of Salmonella was found in the spleen, liver, ovary and caeca of the birds in the four groups during the whole experiment. In general, inactivated Salmonella Enteritidis vaccines was able to decrease the presence of Salmonella Enteritidis in the birds and in the eggs as well. Nevertheless, they must be associated with general hygiene and disinfection practices in poultry husbandry.
\end{abstract}

Key-words: Salmonella Enteritidis, oil-emulsion inactivated vaccines, control, laying hen

\section{INTRODUCTION}

In many countries, outbreaks of human salmonellosis have been occurring since the 1980s. These events are mostly related to the consumption of poultry products, specially eggs and food containing raw eggs contaminated by Salmonella enterica serovar Enteritidis $(3,26,28,35)$.
Salmonella Enteritidis was introduced in poultry flocks mainly by vertical transmission. Once Salmonella Enteritidis reaches a flock of birds it is easily disseminated through the feces $(11,34)$ and remains in the environment $(16,40)$. Therefore, commercial birds may be contaminated throughout their lives. The Salmonella control program should pay attention to the vertical via in addition to other measures taken during the birds'

*Corresponding Author. Mailing address: Departamento de Patologia Veterinária da Faculdade de Ciências Agrárias e Veterinárias da UNESP, Campus de Jaboticabal / Department of Animal Pathology, FCAV UNESP, Jaboticabal. Tel.: (16) 3204 2468, (16) 8145 8727. E-mail:oliveirocaetano@yahoo.com.br 
life. Inactivated Salmonella Enteritidis vaccines have been used in several countries $(9,21,22,37,39)$ and in some of them they have been used in breeder flocks $(13,30,39)$.

The inconvenience of using inactivated Salmonella Enteritidis vaccines is the need for individual application and the reaction caused by the lipopolysaccharide bacterium plus the adjuvant vaccine. Nevertheless, there is a chance of including these vaccine antigens in other polyvalent inactivated preparations that have already been adopted. In addition, since they do not have live Salmonella Enteritidis cells there is no harm to public health.

The efficacy of vaccine preparation is judged by the level of intestinal and systemic colonization, morbidity and mortality rates after vaccination and experimental infection using the oral or parenteral routes of administration. However, the level of protection depends on the challenge strain, the route of administration, infection dose, bird age and species/line/breed. Consequently, it is difficult to compare the efficacy of the currently available vaccine preparations precisely (37).

Inactivated vaccines have been used to control non-specific host Salmonella infections in poultry with varying success $(9,17,21,22,30,33,36)$. Thus, several publications are favorable to their application due to the reduction of fecal shedding and decrease in organ colonization and contamination of eggs. Single oral or intramuscular immunization with formalininactivated $S$. Enteritidis at 2 weeks of age decreases fecal shedding and organ colonization of Salmonella Enteritidis after oral infection with $10^{9}$ colony forming units (CFU) at 6 weeks of age (29). The vaccination of hens with oil-emulsion inactivated $S$. Enteritidis vaccine reduced fecal shedding of Salmonella Enteritidis after the challenge. In vaccinated hens, $58 \%$ of fecal samples were positive, while in unvaccinated hens, $81 \%$ were positive (22). Laying hens vaccinated intramuscularly with a commercial inactivated Salmonella Enteritidis vaccine and challenged intravenously with Salmonella Enteritidis culture, produced less Salmonella Enteritidis positive eggs (54/439 batches of eggs) than the unvaccinated ones $(99 / 252$ batches) (39).

The immunization of 38 week old laying hens with an inactivated S. Enteritidis vaccine, followed by a booster four weeks later, reduced colonization of ovary, spleen and fecal shedding of Salmonella Enteritidis after intravaginal challenge. After the challenge, $19 \%$ of the eggs laid by vaccinated hens were positive, resulting in a significantly lower frequency than in unvaccinated hens (37\%) (33). On the other hand, in a field trial conducted in 10 laying hen flocks, there was no difference in the recovering of Salmonella Enteritidis from bird organs and the environment, despite the administration of inactivated Salmonella Enteritidis vaccine (17). In another field study, in which inactivated Salmonella Enteritidis vaccine was administered to laying hens, Salmonella Enteritidis although not completely eliminated, was reduced in the flocks (15). According to Inoue
(27) broiler chicks from vaccinated breeder flock shedded less Salmonella Enteritidis than those from unvaccinated breeder flock after experimental challenge on the first day of life.

Publications on Salmonella control by vaccines present approaches which are much more suitable to experimental conditions than to the real situation in the field. In this study, three commercial vaccines containing inactivated Salmonella Enteritidis cells in oil-emulsion were assessed, trying to simulate field conditions.

\section{MATERIALAND METHODS}

\section{Bacteria}

The challenge was carried out with a mutant strain of Salmonella Enteritidis PT4 resistant to nalidixic acid and spectinomycin $\left(\mathrm{SE} \mathrm{Nal}^{\mathrm{r}} / \mathrm{Spec}^{\mathrm{r}}\right)$. Bacterial cultures were set in $10 \mathrm{~mL}$ LB broth (Difico-244620) incubated in a shaking incubator (100 rev/min) at $37^{\circ} \mathrm{C}$ overnight. This culture contained approximately $2.13 \times 10^{9} \mathrm{CFU} / \mathrm{mL}$.

\section{Experimental animals}

The experiment was carried out with a white light variety of commercial laying hens (Hyline W-36). Four-hundred birds were obtained at one-day-of age. They were reared and fed according to producer recommendations. At 8-weeks they were divided into four groups $\left(\mathrm{V}_{1}, \mathrm{~V}_{2}, \mathrm{~V}_{3}\right.$ and $\left.\mathrm{CG}\right)$ with 100 birds each.

On arrival, the birds were inspected for Salmonella sp according to Zancan et al. (40).

\section{Vaccines}

Three commercial vaccines $\left(V_{1}, V_{2}\right.$ and $\left.V_{3}\right)$ were used which are produced by different companies allowed for use in breeder and commercial laying hen flocks. They contained inactivated Salmonella Enteritidis cells in oil-emulsion. At 8 and 16 weeks of age, the birds in each group were vaccinated intramuscularly as recommended by the manufacturer.

\section{Experimental design}

Groups $V_{1}, V_{2}$ and $V_{3}$ were vaccinated with different vaccines and $C G$ group received no vaccine.

When birds were 20, 25 and 31 weeks old, 13 from each group were transferred to another room and were challenged by being inoculating with $2 \mathrm{~mL}$ neat culture of Salmonella Enteritidis Nal $/$ Spec $^{\mathrm{r}}$.

On the second day after each challenge, the caecal contents, spleen, liver and ovary of three birds from each group were analyzed for Salmonella Enteritidis Nal ${ }^{\mathrm{r}} / \mathrm{Spec}^{\mathrm{r}}$. Twice a week a cloacal swab was taken from each bird and all eggs laid were examined for the presence of Salmonella Enteritidis Nal ${ }^{\mathrm{r}} / \mathrm{Spec}^{\mathrm{r}}$. Birds were sacrificed for the examination of liver, caecal contents and ovaries after four consecutive negative results of cloacal swab examination in all groups. 


\section{Bacteriological analysis}

The bacteriological analysis was carried out as described by Barrow \& Lovell (10) with some modification. The Salmonella Enteritidis Nal${ }^{\mathrm{r}} / \mathrm{Spec}^{\mathrm{r}}$ fecal shedding was inspected by cloacal swabs, which were placed in selenite broth (CM 395, Oxoid) containing novobiocin $(40 \mu \mathrm{g} / \mathrm{mL})(\mathrm{SN})$ incubated overnight at $37^{\circ} \mathrm{C}$ before being plated on Brilliant Green agar (CM 263, Oxoid) containing sodium nalidixate $(100 \mu \mathrm{g} / \mathrm{mL})$ and spectinomycin $(100 \mu \mathrm{g} / \mathrm{mL})$ (BGA NalSpc). In the absence of growth, new plating was performed from the incubated swab. Eggs collected during the experiment were dropped into sterile glass jars, the shell broken and contents mixed by agitation. Yolk from the ovaries was collected in a jar with SN broth. The jars were incubated at $37^{\circ} \mathrm{C}$ overnight, and their contents were plated on BGA NalSpc and incubated at $37^{\circ} \mathrm{C}$. Samples from spleen and liver were homogenized in a pestle and mortar. The tissue homogenates and the caecal contents were mixed and diluted in phosphate-buffered saline, $\mathrm{pH}$ 7.4. The viable count of Salmonella Enteritidis $\mathrm{Nal}^{\mathrm{r}} \mathrm{Spc}^{\mathrm{r}}$ in the samples was estimated by plating aliquots of decimal dilutions on BGA NalSpc incubated overnight at $37^{\circ} \mathrm{C}$. When no Salmonella Enteritidis was found, the first dilution of the sample was added to an equal volume of double-strength $\mathrm{SN}$ broth, which was incubated at $37^{\circ} \mathrm{C}$ overnight and plated on BG NalSpc agar.

\section{RESULTS}

Table 1 shows the results concerning the presence of Salmonella Enteritidis in the spleen, liver and caecal contents two days after each challenge. The presence of Salmonella Enteritidis was similar in the liver and spleen among groups. It was only in the third challenge that Salmonella Enteritidis counting in the caecal contents differed between group $\mathrm{V}_{1}$ and the Control Group $(\mathrm{p}<0.05)$. Salmonella Enteritidis was not recovered from the ovaries. In the second trial, Salmonella Enteritidis was isolated from the caecal contents of two birds, one from the $\mathrm{V}_{1}$ group and the other from the $\mathrm{V}_{2}$ group. In the third trial, Salmonella Enteritidis Nal'Spcr was found in the liver of one bird from the $\mathrm{V}_{2}$ group, in the caecal contents of two birds from the $\mathrm{V}_{2}$ group and in caecal contents of one bird from the $\mathrm{CG}$ group.

Salmonella Enteritidis fecal shedding data are in Table 2. Only in the first trial was the difference between $V_{3}$ group and the control group significant $(\mathrm{p}<0.05)$.

The detection of Salmonella Enteritidis in eggs is shown in Table 3. In general, birds from the control group produced more contaminated eggs than birds from other groups, but the recovery means were variable. In the first challenge, the vaccine used in the laying hens from the $\mathrm{V}_{3}$ group reduced the presence of Salmonella Enteritidis $(\mathrm{p}<0.05)$ and in the last trial all vaccines reduced the presence of Salmonella Enteritidis in eggs $(\mathrm{p}<0.05)$.

\section{DISCUSSION}

Human foodborne salmonellosis has been strongly associated with eggs and egg products contaminated with Salmonella Enteritidis $(3,26,28,35,38)$, although many efforts have been made for the control of Salmonella Enteritidis in laying hens to prevent egg contamination. Following oral infection, Salmonella Enteritidis colonizes the intestinal tract and may invade organs such as the liver, spleen, ovary and

Table 1: Means of viable count $\left(\log _{10}\right)$ of Salmonella Enteritidis Nal ${ }^{\mathrm{r}} / \mathrm{Spec}^{\mathrm{r}}$ of three birds in spleen, liver and caecal contents two days after each challenge.

\begin{tabular}{lccccc}
\hline Tissue & Challenge & \multicolumn{4}{c}{ Treatments } \\
\cline { 3 - 5 } & & $\mathrm{V}_{1}$ & $\mathrm{~V}_{2}$ & $\mathrm{~V}_{3}$ & $\mathrm{CG}$ \\
\cline { 3 - 5 } Spleen & $\mathbf{1 s t}$ & $2.33 \mathrm{~A}$ & $<2.00 \mathrm{~A}$ & $<2.00 \mathrm{~A}$ & $<2.00 \mathrm{~A}$ \\
& 2nd & $<\mathbf{2 . 0 0 A}$ & $<\mathbf{2 . 0 0 A}$ & $<2.00 \mathrm{~A}$ & $<2.00 \mathrm{~A}$ \\
& 3rd & $<2.00 \mathrm{~A}$ & $<2.00 \mathrm{~A}$ & $<2.00 \mathrm{~A}$ & $2.67 \mathrm{~A}$ \\
& & & & \\
Liver & $\mathbf{1 s t}$ & $2.33 \mathrm{~A}$ & $<2.00 \mathrm{~A}$ & $<2.00 \mathrm{~A}$ & $2.30 \mathrm{~A}$ \\
& 2nd & $<\mathbf{2 . 0 0 A}$ & $<\mathbf{2 . 0 0 A}$ & $<\mathbf{2 . 0 0 A}$ & $<\mathbf{2 . 0 0 A}$ \\
& 3rd & $<2.00 \mathrm{~A}$ & $<2.00 \mathrm{~A}$ & $<2.00 \mathrm{~A}$ & $2.33 \mathrm{~A}$ \\
Cecal & & & & \\
contents & $\mathbf{1 s t}$ & $3.36 \mathrm{~A}$ & $2.33 \mathrm{~A}$ & $<2.00 \mathrm{~A}$ & $3.19 \mathrm{~A}$ \\
& 2nd & $2.53 \mathrm{~A}$ & $2.59 \mathrm{~A}$ & $3.07 \mathrm{~A}$ & $3.67 \mathrm{~A}$ \\
& 3rd & $2.67 \mathrm{~B}$ & $3.57 \mathrm{AB}$ & $3.43 \mathrm{AB}$ & $4.50 \mathrm{~A}$ \\
\hline
\end{tabular}

Group of vaccinated $\left(\mathbf{V}_{1}, \mathbf{V}_{2}\right.$ and $\left.\mathbf{V}_{3}\right)$ and unvaccinated $(\mathbf{C G})$ hens; Means followed by different letters in the same line indicate significant differences by Tukey's test $(\mathrm{p}<0.05)$. 
Table 2: Recovery of Salmonella Enteritidis Nal ${ }^{\mathrm{r}} / \mathrm{Spec}^{\mathrm{r}}$ from cloacal samples after each challenge of vaccinated $\left(\mathbf{V}_{\mathbf{1}}, \mathbf{V}_{\mathbf{2}}\right.$ and $\left.\mathbf{V}_{\mathbf{3}}\right)$ and unvaccinated $(\mathbf{C G})$ birds.

\begin{tabular}{|c|c|c|c|c|c|c|c|c|c|c|c|c|c|c|c|c|c|c|c|c|c|c|c|c|c|c|c|c|c|c|c|c|c|c|c|c|}
\hline \multirow{3}{*}{ Dpi } & \multicolumn{12}{|c|}{ 1st Challenge } & \multicolumn{12}{|c|}{ 2nd Challenge } & \multicolumn{12}{|c|}{ 3rd Challenge } \\
\hline & \multicolumn{3}{|c|}{$V_{1}$} & \multicolumn{3}{|c|}{$\mathbf{V}_{2}$} & \multicolumn{3}{|c|}{$\mathbf{V}_{3}$} & \multicolumn{3}{|c|}{ CG } & \multicolumn{3}{|c|}{$V_{1}$} & \multicolumn{3}{|c|}{$\mathbf{V}_{2}$} & \multicolumn{3}{|c|}{$\mathbf{V}_{3}$} & \multicolumn{3}{|c|}{ CG } & \multicolumn{3}{|c|}{$V_{1}$} & \multicolumn{3}{|c|}{$\mathbf{V}_{2}$} & \multicolumn{3}{|c|}{$\mathbf{V}_{3}$} & \multicolumn{3}{|c|}{ CG } \\
\hline & D & $\mathbf{E}$ & $\mathbf{T}$ & D & $\mathbf{E}$ & $\mathbf{T}$ & D & $\mathbf{E}$ & $\mathbf{T}$ & D & $\mathbf{E}$ & $\mathbf{T}$ & D & $\mathbf{E}$ & $\mathbf{T}$ & D & $\mathbf{E}$ & $\mathbf{T}$ & D & $\mathbf{E}$ & $\mathbf{T}$ & D & $\mathbf{E}$ & $\mathbf{T}$ & D & $\mathbf{E}$ & $\mathbf{T}$ & D & $\mathbf{E}$ & $\mathbf{T}$ & D & $\mathbf{E}$ & $\mathbf{T}$ & $\mathbf{D}$ & $\mathbf{E}$ & $\mathbf{T}$ \\
\hline 2 & 0 & 1 & 1 & 0 & 1 & 1 & 0 & 0 & 0 & 1 & 2 & 3 & 0 & 0 & 0 & 0 & 2 & 2 & 0 & 1 & 1 & 0 & 2 & 2 & 0 & 0 & 0 & 0 & 1 & 1 & 0 & 0 & 0 & 0 & 0 & 0 \\
\hline 7 & 0 & 0 & 0 & 0 & 3 & 3 & 0 & 0 & 0 & 0 & 2 & 2 & 0 & 0 & 0 & 0 & 0 & 0 & 0 & 0 & 0 & 0 & 0 & 0 & 0 & 0 & 0 & 0 & 2 & 2 & 0 & 0 & 0 & 0 & 0 & 0 \\
\hline 10 & 0 & 0 & 0 & 0 & 0 & 0 & 0 & 0 & 0 & 0 & 0 & 0 & 0 & 0 & 0 & 0 & 0 & 0 & 0 & 0 & 0 & 0 & 0 & 0 & 0 & 0 & 0 & 0 & 0 & 0 & 0 & 0 & 0 & 0 & 0 & 0 \\
\hline 13 & 0 & 0 & 0 & 0 & 0 & 0 & 0 & 0 & 0 & 0 & 0 & 0 & 0 & 0 & 0 & 0 & 0 & 0 & 0 & 0 & 0 & 0 & 0 & 0 & 0 & 0 & 0 & 0 & 0 & 0 & 0 & 0 & 0 & 0 & 0 & 0 \\
\hline 16 & 0 & 0 & 0 & 0 & 0 & 0 & 0 & 0 & 0 & 0 & 0 & 0 & 0 & 0 & 0 & 0 & 0 & 0 & 0 & 0 & 0 & 0 & 0 & 0 & 0 & 0 & 0 & 0 & 0 & 0 & 0 & 0 & 0 & 0 & 0 & 0 \\
\hline 20 & 0 & 0 & 0 & 0 & 0 & 0 & 0 & 0 & 0 & 0 & 0 & 0 & 0 & 0 & 0 & 0 & 0 & 0 & 0 & 0 & 0 & 0 & 0 & 0 & 0 & 0 & 0 & 0 & 0 & 0 & 0 & 0 & 0 & 0 & 0 & 0 \\
\hline$\Sigma$ & & & & & & & & & & & & & & $0^{a} / 6$ & & & & & & & & & $2^{\mathrm{a}} /$ & & & & & & & 60 & & & & & & $/ 60$ \\
\hline
\end{tabular}

Dpi: days after the challenge; D: positive result in first swab; E: positive result in second plating; $\mathbf{T}$ : Total = D + E; $\mathbf{\Sigma}=$ total of positive cloacal swabs in 60 observations; $a b=$ Means followed by different letters in the line for each challenge indicate significant differences by Chi-Square's test $(\mathrm{p}<0.05)$.

Table 3: Recovery of Salmonella Enteritidis Nal $/$ Spec $^{\mathrm{r}}$ from egg samples after challenge of vaccinated $\left(\mathbf{V}_{\mathbf{1}}, \mathbf{V}_{2}\right.$ and $\left.\mathbf{V}_{3}\right)$ and unvaccinated (CG) birds.

\begin{tabular}{|c|c|c|c|c|c|c|c|c|c|c|c|c|}
\hline \multirow{2}{*}{ Dpi } & \multicolumn{4}{|c|}{ 1st Challenge } & \multicolumn{4}{|c|}{ 2nd Challenge } & \multicolumn{4}{|c|}{ 3rd Challenge } \\
\hline & $\mathbf{v}_{1}$ & $\mathbf{v}_{2}$ & $\mathbf{v}_{3}$ & CG & $v_{1}$ & $\mathbf{v}_{2}$ & $\mathbf{v}_{3}$ & CG & $v_{1}$ & $\mathbf{v}_{2}$ & $\mathbf{v}_{3}$ & CG \\
\hline 1 & 1 & 5 & 1 & 5 & 3 & 3 & 0 & 3 & 2 & 1 & 1 & 4 \\
\hline 2 & 1 & 0 & 0 & 0 & 0 & 0 & 0 & 1 & 0 & 0 & 0 & 0 \\
\hline 3 & 0 & 0 & 1 & 2 & 0 & 0 & 1 & 1 & 0 & 0 & 0 & 1 \\
\hline 4 & 0 & 1 & 0 & 0 & 2 & 1 & 3 & 3 & 0 & 0 & 0 & 1 \\
\hline 5 & 0 & 0 & 0 & 0 & 0 & 0 & 0 & 0 & 0 & 0 & 0 & 1 \\
\hline 6 & 1 & 0 & 0 & 0 & 0 & 0 & 0 & 0 & 0 & 0 & 0 & 0 \\
\hline 7 & 0 & 0 & 0 & 0 & 0 & 0 & 0 & 0 & 0 & 0 & 0 & 1 \\
\hline 8 & 0 & 1 & 0 & 1 & 0 & 0 & 0 & 0 & 0 & 0 & 0 & 0 \\
\hline 9 & 0 & 0 & 0 & 0 & 0 & 0 & 0 & 0 & 0 & 1 & 0 & 0 \\
\hline 10 & 0 & 0 & 0 & 0 & 0 & 0 & 0 & 0 & 0 & 0 & 0 & 0 \\
\hline 11 & 0 & 0 & 0 & 0 & 0 & 0 & 0 & 0 & 0 & 0 & 0 & 0 \\
\hline 12 & 0 & 0 & 0 & 0 & 0 & 0 & 0 & 0 & 0 & 0 & 0 & 0 \\
\hline 13 & 0 & 0 & 0 & 0 & 0 & 0 & 0 & 0 & 0 & 0 & 0 & 0 \\
\hline 14 & 0 & 0 & 0 & 0 & 0 & 0 & 0 & 0 & 0 & 0 & 0 & 0 \\
\hline 15 & 0 & 0 & 0 & 0 & 0 & 0 & 0 & 0 & 0 & 0 & 0 & 0 \\
\hline 16 & 0 & 0 & 0 & 0 & 0 & 1 & 0 & 0 & 0 & 0 & 0 & 0 \\
\hline Pos. * & $3^{a b} / 123$ & $7^{\mathrm{ab} / 136}$ & $2^{b} / 126$ & $8^{a} / 122$ & $5^{a} / 125$ & $5^{a} / 126$ & $4^{a} / 121$ & $8^{a} / 124$ & $2^{b} / 145$ & $2^{b} / 149$ & $1^{b} / 145$ & $8^{a} / 133$ \\
\hline
\end{tabular}

Dpi= days after infection; Pos. ${ }^{*}=$ Number of positive samples/ total eggs examined; $a b=$ Means followed by different letters in the line for each challenge indicate significant differences by Chi-Square's test $(\mathrm{p}<0.05)$.

heart $(10,20)$. In this study, quite a few Salmonella Enteritidis organisms were found in the liver and spleen (Table 1) of birds from all the groups during the experiment, with no difference between vaccinated and unvaccinated birds $(p>0.05)$. These findings might have been expected since Berchieri Jr. et al. (12) demonstrated that Salmonella Enteritidis did not persist longer in mature birds. It was also showed that 20-40 weeks old laying hens are naturally more resistant to Salmonella Enteritidis infection (25). In contrast, the beneficial effect of Salmonella Enteritidis inactivated oil-emulsion vaccines in preventing organ colonization by Salmonella Enteritidis was demonstrated by Nakamura et al. (33) and Gast et al.(21). 
In the present study, Salmonella Enteritidis fecal shedding (Table 2) did differ between the $\mathrm{V}_{3}$ group and the control group in the first challenge $(p<0.05)$. Depending on the composition, the inactivated vaccine can decrease of Salmonella Enteritidis fecal shedding (29). A study conducted by Barbour et al. (5), comparing six inactivated Salmonella Enteritidis vaccines, showed a variable decrease in the Salmonella Enteritidis fecal shedding. These authors suggested that several factors regarding the type and composition of the adjuvant, strain of Salmonella Enteritidis and inactivation method, could be responsible for this variation, and could explain the results depicted in Table 2. Unfortunately, not all information on the commercial vaccines used was available.

It is proposed that cell-mediated immunity is more important for tissue clearance of Salmonella Enteritidis, while humoral response seems to be responsible for the reduction of intestinal colonization $(6,7,24,32,37)$. One of the criteria for an ideal vaccine is the promotion of bird protection against mucosal and systemic infection by effective stimulation of both immune responses (37). Some authors showed that the Salmonella Enteritidis inactivated vaccines induce only a good humoral immune response, which reduces the intestinal colonization by Salmonella Enteritidis $(4,6,14,18,24,32)$. This might be in the reason for the decrease of Salmonella Enteritidis in bird feces (caecal Salmonella Enteritidis counting and cloacal swabs) of the $V_{1}$ and $V_{3}$ groups (Tables 1 and 2) in the present work.

There was a positive effect of the vaccination of birds in the $\mathrm{V}_{3}$ group in the first challenge and in all the groups of vaccinated birds in the third challenge (Table 3 ). These results are in agreement with previous works in which the presence of Salmonella Enteritidis in eggs laid was reduced by a vaccination program using an inactivated vaccine $(21,30$ e 39$)$. About $68.2 \%$ of the outbreaks of human foodborne salmonellosis caused by Salmonella Enteritidis is related to egg and food containing raw eggs (31), despite the fact that one out of 20,000 eggs laid is supposed to be contaminated by Salmonella Enteritidis (19). Therefore, any reduction is very welcome. In addition, inactivated vaccines may induce enough passive immunity to protect the progeny (27).

In the first and second challenges, it was possible to observe some correlation between Salmonella Enteritidis in feces and in eggs. Similar results were observed by Gast \& Beard (20) and Woodward et al. (39). According to Barrow \& Lovell (10) eggs are mainly contaminated with Salmonella Enteritidis by contact with fecal material in the cloacae, although transovarian contamination also occurs.

Intrinsic factors in the eggshell and in the albumen may interrupt the multiplication of Salmonella. At low temperatures, Salmonella can be kept viable in the yolk (2) and can multiply in $72 \mathrm{hs}$, at $15^{\circ} \mathrm{C} \mathrm{(1),} \mathrm{and} \mathrm{in} \mathrm{hot} \mathrm{weather} \mathrm{these} \mathrm{factors} \mathrm{become}$ less active. Thus, the best way to prevent human foodborne salmonellosis is by taking precautions during the bird's lifetime.
It is known that Salmonella Enteritidis may persist in vaccinated flocks of laying hens (15). But in view of the results obtained in this work, a vaccination program to control the presence of Salmonella Enteritidis in laying hens can be adopted as an additional tool to minimize the presence of Salmonella Enteritidis in eggs, in association with general practices of hygiene and disinfection in poultry husbandry.

\section{ACKNOWLEDGEMENTS}

The authors would like to thank Mr. Antonio Jose dos Santos and Mrs. Aparecida Rodrigues Baptista for all the assistance and FAPESP and CNPq for the financial support.

\section{RESUMO}

\section{"Controle de Salmonella enterica sorovar Enteritidis em poedeiras comerciais com a utilização de vacinas inativadas"}

Salmonella Enteritidis é um dos agentes responsáveis por toxinfecção alimentar em humanos e tem sido associada a alimentos de origem avícola. Entre os métodos disponíveis para o seu controle está a vacinação de poedeiras e matrizes com vacinas inativadas (bacterinas). Os resultados a respeito da proteção das bacterinas contra Salmonella Enteritidis em aves são variados. Face à inexistência de dados referentes ao uso dessas vacinas no Brasil, realizou-se o presente trabalho. Foram utilizadas 400 pintinhas de uma linhagem de postura leve. $\mathrm{Na} 8^{\circ}$ semana de idade, as aves foram divididas em quatro grupos $\left(\mathrm{V}_{1}\right.$, $\mathrm{V}_{2}, \mathrm{~V}_{3}$ e CG). Três diferentes bacterinas comerciais foram administradas às aves do $V_{1}, V_{2} e V_{3}$ em duas doses, na $8^{\circ} \mathrm{e} 16^{\circ}$ semanas de vida; as do CG não receberam vacina. Treze aves por grupo foram infectadas com Salmonella Enteritidis nas $20^{\circ}$, $25^{\circ} \mathrm{e} 31^{\circ}$ semanas. No $2^{\circ}$ dia após cada desafio foram sacrificadas três aves por grupo, para contagem de Salmonella Enteritidis em fígado, baço, conteúdo cecal e pesquisa do microrganismo no ovário. Suabes de cloaca foram realizados dois dias pósinfecção (dpi) e duas vezes por semana. Todos os ovos foram examinados. Após a ausência de Salmonella Enteritidis em quatro suabes de cloaca consecutivos, esse microrganismo foi pesquisado em fígado, conteúdo cecal e ovário. Não houve diferença da contagem de Salmonella Enteritidis nos órgãos. O conteúdo cecal das aves do $\mathrm{V}_{1}$ teve menos Salmonella que as do CG. As aves do $\mathrm{V}_{3}$ excretaram menos Salmonella em fezes e ovos. Conforme os resultados observados no $\mathrm{V}_{3}$, é possível reduzir excreção de Salmonella Enteritidis com o uso de bacterinas; contudo, deve ser utilizado de forma complementar a boas práticas de manejo, limpeza e desinfecção.

Palavras-chave: Salmonella Enteritidis, vacinas oleosas inativadas, controle, poedeiras 


\section{REFERENCES}

1. Almonacid, S.; Gutierrez, J.; Jaques, A.; Simpson, R. (2002). Salmonella Enteritidis risk assessment: A kinetic analysis. J. Food Sci., 67 (3), 115-1120

2. Al-Saffar, A.A.; Rose, S.P. (2002). Ambient temperature and the egg laying characteristics of laying fowl. Pout Sci., 58 (3), $317-$ 331.

3. Araújo, E.; Pacheco, M.; Boni, R.F.; Fonseca, Y.S.K.; Gelli, D.S.; Fernandes, S.A.; Tavechio, A.T. (1995). Surtos alimentares por Salmonella enteritidis associados ao consumo de alimentos à base de ovos em Sorocaba, SP. Higiene Aliment., 9 (5), 24-26.

4. Arnon, R.; Shapira, M.; Jacob, C.O. (1983). Synthetic vaccines. J. Immnol. Metholds., 61(3), 261-273.

5. Barbour, E.K.; Frederichs, W.M.; Nabbut, N.H.; Poss, P.E. (1993). Evaluation of bacterin containing three predominant phage types of Salmonella Enteritidis for prevention of infection in egg-laying chickens. Am. J. Vet. Res., 54 (8), 1306-1309.

6. Babu, U.; Dalloul, R.A.; Okamura, H.S.; Lillehoj, H.; Xie, H.; Raybourne, R.B.; Gaines, D.; Heckert, R.A. (2004). Salmonella Enteritidis clearance and responses in chickens following Salmonella vaccination and challenge. Vet. Immunol. Immunophatol., 101 (3), 251-257.

7. Barrow, P.A.; Wallis, T.S (2000). Vaccination against Salmonella infections in food animals: rationale, theoretical basis and practical application. In: Wray, C. (Ed.) Salmonella in domestic animals. CAB International, Oxford, England, p.323-339.

8. Barrow, P.A. (1999). Salmonella infections in poultry - problems and new thoughts on the possibilities of control. Braz. J. Poult. Sci., 1 (1), 9-16.

9. Barrow, P.A.; Hassan, J.O.; Berchieri Júnior, A. (1990). Reduction in faecal excretion of Salmonella typhimurium strain F98 in chickens vaccinated with live and killed S. typhimurium organisms. Epidemiol. Infect., 104 (3), 413-426.

10. Barrow, P.A.; Lovell, M.A. (1991). Experimental infection of egglaying hens with Salmonella Enteritidis phage type 4. Avian Pathol., 20 (4), 335-338.

11. Berchieri Júnior, A (2000). Salmoneloses aviárias. In: Berchieri Júnior, A.; Macari, M. Doenças das aves. FACTA, Campinas, Brasil, p. 185-195.

12. Berchieri, A.; Wigley, P.; Page, K.; Murphy, C.K.; Barrow, P.A. (2001). Further studies on vertical transmission and persistence of Salmonella enterica serovar Enteritidis phage type 4 in chickens. Avian Pathol., 30 (4), 297-310.

13. Brazil. Brazilian Ministry of Agriculture, Livestock and Supply. National program of avian health. Directive ("Instrução Normativa") number 78. Official Newspaper of the Government of Brazil, Brasília, november 5, 2003.

14. Collins, F.M. (1972). Effect of adjuvant on immunogenicity of heatKilled vaccine. J Infect Dis., 126 (1), 69-76.

15. Davies, R.; Breslin, M. (2004). Observations on Salmonella contamination of eggs from infected commercial laying flocks where vaccination for Salmonella enterica serovar Enteritidis had been used. Avian Pathol., 33 (2), 133-144.

16. Davies, R.H.; Wray, C. (1996). Studies of contamination of three broiler breeder houses with Salmonella enteritidis before and after cleaning and disinfection. Avian Dis., 40 (1), 626-633.

17. Davison, S.; Benson, C.E.; Henzler, D.J.; Eckoroade, R.J. (1999). Field observations with Salmonella enteritidis bacterins. Avian Dis., 43 (4), 664-669.

18. Desmidt, M.; Ducatelle, R.; Mast, J.; Goddeeris, M.; Kaspers, B.; Haesebrouck, F. (1998). Role of the humoral immune system in
Salmonella Enteritidis phage type four infection in chickens. Vet. Immun., 63 (4), 355-367.

19. Ebel, E; Schlosser, W. (2000). Estimating the annual fraction of eggs contaminated with Salmonella Enteritidis in the United States. J. Food Microbiol., 61 (1), 51-62.

20. Gast, R.K.; Beard, C.W. (1990). Production of Salmonella Enteritidis contaminated eggs by experimentally infected hens. Avian Dis., 34 (2), 438-446.

21. Gast R.K.; Stone, H.D.; Holt, P.S.; Beard, C.W. (1992). Evaluation of the efficacy of an oil-emulsion bacterin for protecting chickens against Salmonella Enteritidis. Avian Dis., 36 (4), 992-999.

22. Gast, R.K.; Stone, H.D.; Holt, P.S. (1993). Evaluation of the efficacy of oil-emulsion bacterins for reducing fecal shedding of Salmonella Enteritidis by laying hens. Avian Dis., 37 (4), 1085-91.

23. Gast, R.K.; Guard-Bouldin, J.; Holt, P.S. (2004). Colonization of reproductive organs and internal contamination of eggs after experimental infection of laying hens with Salmonella heidelberg and Salmonella enteritidis. Avian Dis., 48 (4) 863-869.

24. Hassan, J.O.; Curtiss Iii, R. (1990). Control of colonization by virulent Salmonella Typhimurium by oral immunization of chickens with avirulent delta cya delta crp $S$ Typhimurium. Res. Microbiol., 142 (1), 839-850.

25. Humphrey, T.J.; Chart, H.; Baskerville, A.; Rowe, B. (1991). The influence of age on the response of SPF hens to infections with Salmonella Enteritidis PT4. Epidemiol. Infect., 106 (4), 33-43.

26. Humphrey, T.J. (2006). Are happy chickens safer chickens? Poultry welfare and disease susceptibility. Br. Poult. Sci., 47 (4), 379390 .

27. Inoue, Y.A. (2006). Estudo da imunidade passiva em progênie de aves vacinadas com bacterina contra Salmonella Enteritidis. Jaboticabal, Brasil, 80p. (M.Sc, Tese. Faculdade de Ciências Agrárias e Veterinárias. UNESP).

28. Kaku, M.; Peresi, J.; Tavechio, A.T.; Fernandes, A.S.; Batista, A.B.; Castanheira, I.; Garcia, G.; Irino, K.; Gelli, D. (1995). Surto alimentar por Salmonella enteritidis no Noroeste do Estado de São Paulo, Brasil. Rev. Saude Publica., 29 (2), 127-131.

29. Liu, W.; Yang, Y.; Chung, N.; Kwang, J. (2001). Induction of humoral immune response and protective immunity in chickens against Salmonella enteritidis after a single dose of killed bacterium-loaded microspheres. Avian Dis., 45 (4), 797-806.

30. Miyamoto, T.; Kitaoka, D.; Withanage, G.S.; Fukata, T.; Sasai, K.; Baba, E. (1999). Evaluation of the efficacy of Salmonella Enteritidis oil-emulsion bacterin in an intravaginal challenge model in hens. Avian Dis., 43 (3), 497-505.

31. Morris, G.K. (1990). Salmonella Enteritidis and eggs: assessment of risk. Dairy Food Environ. Sanit., 10 (3), 279-281.

32. Saeed, A.M. (1999). Salmonella enterica serovar Enteritidis in humans and animals. State University Press. Ames Iowa.

33. Nakamura, M.; Nagamine, N.; Takashi, T.; Suzuki, S.; Sato, S. (1994). Evaluation of the efficacy of a bacterin against Salmonella Enteritidis infection and the effect of stress after vaccination. Avian Dis., 38 (4), 717-724.

34. Plym Forshell, L; Wierup, M. (2006). Salmonella contamination: a significant challenge to the global marketing of animal food products. Rev. Sci. Tech. Off. Int. Epiz., 25 (2), 541-554.

35. Rodrigue, D.C.; Tauxe, R.V.; Rowe, B. (1990). International increase in Salmonella Enteritidis: a new pandemic? Epidemiol. Infect., 105 (1), 21-27.

36. Timms, L.M.; Marshal, R.N.; Breslin, M.F. (1990). Laboratory assessment of protection given by an experimental Salmonella Enteritidis PT4 inactivated, adjuvant vaccine. Vet. Rec., 127 (25), 611-614. 
Freitas-Neto, O.C. et al.

37. Van Immerseel, F.; Methner, U.; Rychlik, I.; Nagy, B.; Velge, P.; Martin, G.; Foster, N.; Ducatelle, R.; Barrow, P.A. (2005). Vaccination and early protection against non-host-specific Salmonella serotypes in poultry: exploitation of innate immunity and microbial activity. Epidemiol. Infect., 133 (6), 959-978.

38. Vege, P.; Cloeckaert, A.; Barrow, P. (2005). Emergence of Salmonella epidemics: The problems related to Salmonella enterica serotype Enteritidis and multiple antibiotic resistence in orther major serotypes. Vet. Res., 36 (3), 267-288.
39. Woodward, M.J.; Gettingby, G.; Breslin, M.F.; Corkish, J.D.; Houghton, S. (2002). The efficacy of Salenvac, a Salmonella enterica subsp. Enterica serotype Enteritidis iron-restricted bacterin vaccine, in laying chickens. Avian. Patol., 31 (4), 383-392.

40. Zancan, F.B.; Berchieri Júnior, A.; Fernandes, S.A.; Gama, N.M.S.Q. (2000). Salmonella spp investigation in transport box of day old birds. Braz. J. Microbiol., 31 (3), 230-232. 